\title{
EXAMINING SOME OF THE RAISONS D'ÊTRE FOR THE ETHIOPIAN ANTI-TERRORISM LAW
}

\begin{abstract}
There has been a proliferation of counter-terrorism legislation around the world following $9 / 11$, a turning point in the history of counter-terrorism. Ethiopia passed its anti-terrorism law in July 2009. This law and its application have been controversial since its promulgation. A debate on several issues relating to the law and its (mis)application was held in August 2013. Whether the law is needed at all was one of the contentious issues deliberated on. Proponents argue that the clear and present danger of terrorism in Ethiopia coupled with inadequacy of ordinary laws to deal with this reality necessitated the law. They also contend that the United Nations Security Council resolution 1373 (2001) requires Ethiopia to pass the law. Challengers dismiss these justifications as pretexts and maintain that the real reason for passing the law is to discipline dissent and crack down on opposition. This article scrutinizes the aforementioned justifications for the law and concludes that they are invalid.
\end{abstract}

Wondwossen Demissie Kassa *

\section{Key terms}

Ethiopian anti-terrorism law, Domestic terrorism, SC Resolution 1373, Report to CTC

DOI http://dx.doi.org/10.4314/mlr.v7i1.3

\section{Introduction}

Ethiopia passed the Anti-terrorism Proclamation 652/2009 in July 2009. The proclamation and its application have been contentious since its promulgation. ${ }^{1}$ In August 2013, Ethiopian Television and Radio Agency had hosted a debate ${ }^{2}$

\footnotetext{
* LL.B (Addis Ababa University Law School), LL. M. (University of Michigan Law School), PhD student at Flinders University of South Australia.

Email: wondwossend@yahoo.com

${ }^{1}$ Human Rights Watch expressed its concern about the law in its draft stage. See: Human Rights Watch (2009), An Analysis of Ethiopia's Draft Anti-Terrorism Law, $<$ http://www.hrw.org $>$. Amnesty International (2011), dismantling dissent intensified crackdown on free speech in Ethiopia, <http://www.amnesty.org>; Committee to Protect Journalists (2009), Anti-terrorism legislation further restricts Ethiopian press. $<$ http://cpj.org $>$. By way of introduction the journalist who hosted the debate on ETV 2 see: acknowledges this ongoing controversy.

$<\mathrm{http} / /$ www.youtube.com/watch?v=sABjG94eT3Ehttp://www.youtube.com/watch?v=g5JhwpAt4Uhttp://www.youtube.com/watch?v=Nr76bQEtnlA>
} 
among political parties ${ }^{3}$ on range of issues relating to the Ethiopian antiterrorism law and its application.

One of the issues raised and debated on was the raisons d'être for promulgating the proclamation. Among the justifications provided in the preamble of the law, three were raised and discussed during the debate. Representatives of the Ethiopian Peoples' Revolutionary Democratic Front (EPRDF), the ruling party, argued that the existence of clear and present danger of terrorism in Ethiopia coupled with the inadequacy of ordinary laws to deal with this reality called for special anti-terrorism legislation. Representative of the Ethiopian Democratic Party, one of the four opposition political parties that participated in the debate, referred to the obligation of states to pass antiterrorism legislation imposed by UN Security Council resolution 1373 (2001), which was echoed by the representatives of EPRDF, as another justification for the enactment of the law. According to this view, there is a consensus at the United Nations level that terrorism is a global challenge as a result of which the Security Council instructs every state, including Ethiopia, to pass anti-terror laws.

Representatives of the other opposition political parties, on the other hand, argued that although there have been incidents of terrorist attacks, the threat of terrorism in Ethiopia has not been to an extent that justifies the special antiterror law. They claimed that the anti-terrorism proclamation is passed with a view to use it as a tool to dismantle political opposition and dissent.

This article investigates the validity of the arguments advanced to justify the promulgation of the Ethiopian anti-terrorism proclamation: domestic realitiesthreat of terrorism and lack of appropriate law to cope with the threat-and obligation under international instruments. ${ }^{4}$ The first section examines EPRDF's claim that the existence of clear and present danger of terrorism in Ethiopia justifies the Proclamation. This part evaluates the evidence that EPRDF cited and relied on, during the debate, to show the existence of clear and present danger in light of Ethiopia's reports to UN Security Council Counter Terrorism Committee (CTC). Sections 2 to 4 examine whether or not the Security Council resolution 1373 (2001) obliges States to pass laws on domestic terrorism.

3 Five political parties participated in the debate. They are Ethiopian Peoples' Revolutionary Democratic Front (EPRDF), the ruling party, Ethiopian Democratic Party, Blue Party, Unity for Democracy and Justice Party, and Ethiopian Federal Democratic Unity Forum. Members with senior positions represent the parties.

${ }^{4}$ Note that this article merely scrutinizes the reasons claimed during the debate as justifying the enactment of the law. By so doing, it does not assume that these are the only reasons for passing the law, nor does it explore and evaluate validity of other possible reasons. 
Finally, the article, without taking position on the rightness of having the anti-terrorism law, concludes that the evidence produced to justify the antiterrorism law is unconvincing.

\section{Threat of Terrorism and Inadequate Law as Justification}

One of the justifications for the promulgation of the anti-terrorism proclamation is that Ethiopia has faced a clear and present danger of terrorism and the substantive and procedural laws in place were not capable of addressing this problem. ${ }^{5}$ In showing the seriousness of the problem, EPRDF went to the extent of asserting that Ethiopia is much more exposed to terrorism even as compared to Afghanistan and the United States. ${ }^{6}$

The evidence that the representatives of EPRDF invoke to buttress their claim are predominantly terrorist acts which were committed before 2000 . The footage of terrorist attacks was displayed during the debate which includes the bombings on Wabe Shebelle Hotel, Dire Dawa Ras Hotel, and Blue Tops, all of which occurred over a decade ago.

Security Council resolution 1373 which provides for a series of obligations on States established the CTC (Counter Terrorism Committee) to follow up progress in the implementation of the resolution by member states. Paragraph six of the resolution calls upon States to report to the CTC as to the steps they took to discharge their obligation in the resolution. A brief look at Ethiopia's initial reports is helpful to know whether the government of Ethiopia believed, from the beginning, that the threat of terrorism in Ethiopia is real and serious, and special anti-terrorism law is needed.

${ }^{5}$ A document that provides for the legislative background of the Proclamation indicates that the inadequacy of the existing laws to effectively prevent and control terrorism had got the utmost attention of the House. Third Round House of Peoples' Representatives of the Federal Democratic Republic of Ethiopia, 2008-2009, Approved Proclamations, Public Discussions and Recommendations, Volume 7, pp. 71-72.

${ }^{6}$ According to the Global Terrorism Index 2011, Afghanistan ranked $3^{\text {rd }}$ next to Iraq and Pakistan, Ethiopia ranked $37^{\text {th }}$ and United States ranked $41^{\text {st }}$ in terms of the impact terrorism caused on countries. According to this source, Ethiopia is the least affected by terrorism next to Djibouti compared with neighbouring countries. Somalia, Sudan, Kenya, Uganda and Eritrea respectively ranked $6^{\text {th }}, 11^{\text {th }}, 18^{\text {th }}, 30^{\text {th }}$ and $35^{\text {th }}$. The Global Terrorism Index measures the impact of terrorism in 158 countries since 2001 by aggregating four indicators: the number of terrorist incidents, fatalities, injuries and property damage. The index is based on data from the Global Terrorism Database, which is collected and collated by the National Consortium for the Study of Terrorism and Responses to Terrorism (START), headquartered at the University of Maryland. The Institute for Economics and Peace (2012), Global Terrorism Index. http://visionofhumanity.org/sites/default/files/2012_Global_Terrorism_Index_Report.pdf 
In its first report to the CTC in January 2002, the Ethiopian government expressly stated Ethiopia's vulnerability and actual exposure to terrorist attacks launched from al-Qaeda and the Somalia based Islamic group Al-Ittihad AlIslamia. ${ }^{7}$ While acknowledging its vulnerability to terrorism, citing different legal instruments including the 1957 Criminal Code and the 1974 Special Penal Code, Ethiopia officially expressed its position that its existing laws were adequate for its counter terrorism in general and to prosecute perpetrators of terrorist attacks that had occurred hitherto in particular. ${ }^{8}$ In its 13-page supplementary report of 31 October 2002, the Ethiopian government reaffirmed its position and confidently explained how the different provisions of its domestic laws can be used to fight terrorism. ${ }^{9}$

As evidence of the competence of its law to deal with terrorism, Ethiopia cited practical anti-terrorism activities including that offenders who were involved in the attempted assassination of former Egyptian president Hosni Mubarek were successfully tried, convicted and sentenced. ${ }^{10}$ Another case cited in the report as example to demonstrate the adequacy of the law was the case involving Al-Ittihad Al-Islamia terrorists, who attempted to assassinate Dr Abdulmejid Hussein, former Ethiopian Minster of Transport and Communications. ${ }^{11}$ Addressing the concern of the CTC on the absence of a specific provision criminalizing terrorism, Ethiopia indicated that a provision that expressly criminalizes a terrorist act has been incorporated in the then draft Criminal Code. ${ }^{12}$

${ }^{7}$ Letter dated 30 January 2002 from the Chargé d'affaires of the Permanent Mission of Ethiopia to the United Nations addressed to the Chairman of the Security Council Committee established pursuant to resolution 1373 (2001) concerning counterterrorism (hereafter the report), S/2002/137, p. 3.

$<$ http://daccess-ddsny.un.org/doc/UNDOC/GEN/N02/241/52/PDF/N0224152.pdf?OpenElement>

${ }^{8}$ Ibid ; Letter dated 31 October 2002 from the Permanent Representative of Ethiopia to the United Nations addressed to the Chairman of the Security Council Committee established pursuant to resolution1373 (2001) concerning counter-terrorism, (hereafter supplementary report) S/2002/1234, p. 3. Available at:

$<$ http://daccess-ddsny.un.org/doc/UNDOC/GEN/N02/690/69/PDF/N0269069.pdf?OpenElement>

${ }^{9}$ Ibid.

${ }^{10}$ The Report, supra note 7, p. 6

${ }^{11}$ Ibid.

${ }^{12}$ Ibid, p. 4. This was more explicitly stated in the supplementary report, supra note 8 , which reproduces the provision as follows:

"Article 252. Terrorist Act

1. Whosoever commits a terrorist act which may endanger the life, physical integrity or freedom of, or causes serious injury or death to, any person, any number or group of 
Though the initial position of the Ethiopian government, based on its consecutive country reports to the CTC, was that it can fight terrorism with the existing laws, it passed the special anti-terrorism proclamation in 2009. The reason for the shift from the position that there are adequate ordinary laws for countering terrorism to that of advocating for the need to have special antiterrorism law did not explicitly transpire during the debate. Yet, the representatives of EPRDF strongly argued that there is a clear and present danger of terrorism to justify the promulgation of the special law. To justify the law passed in 2009, one of the representatives cited terrorist acts committed a decade before the promulgation of the law. What makes this odd is that the reports to the CTC in which the government in clear terms state the adequacy of the then existing law were prepared after the commission of these terrorist acts which were cited as evidence of the gravity of the problem of terrorism in Ethiopia to call for special law.

The logical oddity of EPRDF's usage of the pre-report terrorist attacks to justify the promulgation of the anti-terrorism proclamation is apparent when one notes how the case of attempted assassination of former Egyptian president Hosni Mubarek was used. As stated above, this case was cited in Ethiopia's 2002 report to the CTC as evidence to show how successful the government had been in fighting terrorism with ordinary substantive and procedural criminal laws. Contrary to this, the case of Hosni Mubarek was raised, during the debate, as evidence to justify the need for the special anti-terrorism law.

In view of Ethiopia's 2002 threat assessment, for seriousness of the threat of terrorism to be cited as a good reason for the government to introduce a special law on terrorism, the government should have had evidence to show that the threat of terrorism has increased since 2002 and that the laws which were adequate to deal with terrorist attacks and threats up until 2002 are no longer sufficient to cope with the increasing threat. However, no evidence was

persons, or causes or may cause damage to public or private property, natural resources, environment or cultural heritage and is calculated or intended to:

(a) Intimidate, put in fear, force, coerce or seduce any government, body, institution, the general public or any segment thereof, to do or abstain from doing any act, or to adopt or abandon a particular standpoint, or to act according to certain principles; or

(b) Disrupt any public service, the delivery of any essential service to the public or to create a public emergency; or

(c) Create general insurrection in a state; is punishable with rigorous imprisonment from ten to twenty five years; or in grave cases, with rigorous imprisonment for life or death.

2. Any promotion, sponsoring, contribution to, command, aid incitement, encouragement, attempt, threat, conspiracy, organizing, or procurement of any person, with intent to commit any of the acts referred to in Sub-article (1) of this Article shall be punished in accordance with Sub-Article (1) hereof (emphasis added)." Supplementary report, supra note 7, pp. 3- 4. 
produced to warrant this conclusion. Apart from indicating that the new law has made it possible for the Ethiopian security forces to foil a good number of terrorist plots and to investigate and prosecute terrorist acts, no point was made, for example, to show that this would not have been possible under the ordinary laws. No mention of terrorist acts which escaped investigation and prosecution due to the shortcomings of ordinary criminal laws was made. The terrorist acts in the footage shown in the middle of the debate, supposedly justifying the law, were committed before the 2002 report.

The incidents cited by promoters of the Anti-terrorism Proclamation during the debate being predominantly those which occurred prior to 2002, there seems no convincing evidence to show that there has been an increase in terrorism threat after 2002. In the absence of evidence to show the change in the level of threat, reference to the terrorist attacks that took place prior to 2002, which were not then considered as too difficult to be addressed by the then ordinary laws, to justify the anti-terror law passed in 2009 is not thus logical and convincing.

\section{Obligation under International Legal Instruments as Justification}

The other justification that EPRDF put forward when challenged on the need to have the anti-terror law is Ethiopia's obligation imposed by the Security Council resolution 1373 to pass anti-terrorism legislation. ${ }^{13}$ This resolution was mentioned as the major international instrument requiring states to pass antiterror laws in the document that shows the legislative background of the Ethiopian Anti-terrorism Proclamation. ${ }^{14}$ The Ethiopian anti-terrorism proclamation has been predominantly used against Ethiopians ${ }^{15}$ who are alleged to have committed terror-related acts within the territory of Ethiopia--domestic terrorism. ${ }^{16}$ This section investigates the scope of resolution 1373 - whether it imposes obligation on the states to pass laws applicable to domestic terrorism.

\footnotetext{
${ }^{13}$ See supra note 3

${ }^{14}$ Third Round House of peoples' Representatives, supra note 5, p. 70.

${ }^{15}$ Right from the beginning Ethiopia has been defending the law on the ground that "the country has a right to defend itself against rebels." Christian Ehret (2009), "Ethiopia lawmakers pass controversial new anti-terrorism law", Jurist, July 2009. While recognizing the international element, Woldeselase observes that it is mainly rise of domestic terrorism that triggers Ethiopia's counterterrorism activity. Woldeselase Woldemichael (2010), Terrorism in Ethiopia and the Horn of Africa; threat, Impact and Response, p. 285 $<$ http://jurist.org/paperchase/2009/07/ethiopia-lawmakers-pass-controversial.php>

${ }^{16}$ Imobighe distinguishes domestic from international terrorism as follows:

"Domestic terrorism relates to those acts of terrorism that are carried out by persons or local groups within the state that are meant to redress domestic grievances. This is distinct from international terrorism, which relates to terrorist acts by persons or
} 
A good starting point is to refer to the resolution itself. The preamble of the resolution provides the background in light of which the resolution's operational part shall be interpreted. It seems to suggest that the resolution is concerned with international terrorism. First the two previous Security Council resolutions ${ }^{17}$ to which the resolution makes reference in the first paragraph of its preamble deal with international terrorism. Second, the resolution, in the $2^{\text {nd }}$ and $3^{\text {rd }}$ paragraphs

groups that are external to the affected state and whose objective is to advance an extraterritorial cause."

Thomas A. Imobighe, in WafuluOkumu and Anneli Botha (editors) (2007), "Challenges in categorising domestic terrorism", Domestic terrorism in Africa: Defining, addressing and understanding its impact on human security, p. 16. Andrews Atta-Asamoah suggests making use of the approach used in the treaty on transnational organized crimes to differentiate domestic from transnational terrorism. As provided under article 3(2) of the Convention, an offence is said to be transnational in nature if it is committed in:

- more than one state,

- one state but has a substantial part of its preparation, planning, direction or control taking place in another state

- one state but involves an organised group that engages in activities in more than one state

- one state but has substantial effects in another state. ${ }^{16}$

Thus, by applying the convention's definition by analogy, Atta-Asamoah treats a terrorist act as transnational if more than one territory can be identified with the planning, preparation, targeting, execution and effects of that act. For him, "any act of terrorism that occurs within the confines of a single state boundary without the involvement of groups with transnational spread and does not have the effects that transcend national boundaries can be considered domestic terrorism."Andrews AttaAsamoah, in Wafulu Okumu and Anneli Botha (eds.) (2007), "Transnational and domestic terrorism in Africa Any linkages?", Domestic Terrorism in Africa: Defining, addressing and understanding its impact on human security, p.20.

Critics on categorizing terrorism into domestic and transnational maintain that the distinction between the two is basically artificial having no analytical leverage and hence unacceptable. Ignacio Sanchez-Cuenca and Luis de la Calle (2009), Domestic Terrorism: The Hidden Side of Political Violence.

$<$ http://www.annualreviews.org/doi/pdf/10.1146/annurev.polisci.12.031607.094133 @ violence.2013.1.issue-1>

Atta-Asamoah questions the tenability of the categorization of terrorism into domestic and international in the age of globalization. He argues "under the forces of globalisation --- an event anywhere is an event everywhere and therefore any terrorist event anywhere is a concern everywhere as the effects transcend state boundaries. This has blurred the practicality of the divide between domestic and transnational terrorism making the categorisation only a theoretical construct without practical substance." Atta-Asamoah (2007), p. 26

${ }^{17}$ Resolution 1269 (1999) and resolution 1368 ( 2001) 
of its preamble, reaffirms ${ }^{18}$ the Security Council's condemnation of the 9/11 terrorist attacks and other 'such' acts which, like any act of international terrorism, constitute a threat to the international peace and security. That resolution 1373 was passed following 9/11, which is indubitably an international terrorist attack, and that the resolution refers to terrorist acts which are of similar nature with 9/11 suggest that the Security Council passed resolution 1373 by having international but not domestic terrorism in mind. The discussion of the High-level Security Council's meeting held on the first anniversary of 9/11 was confined to international terrorism, ${ }^{19}$ and this gives credence to this interpretation of the resolution.

Though disapprovingly, many scholars agree that the global counterterrorism has transnational terrorism in mind. ${ }^{20}$ As a reflection of the US' dominant interests, Cilliers observes, there is a global pre-occupation with terrorist groups having 'global reach.' Atta-Asamoah notes that possibly because the "counterterrorism agenda in Africa is Western driven, serves the interests of Western actors, and seeks to enhance the safety of Western lives rather than that of Africans" 22 many counter-terrorism measures and initiatives in Africa are primarily concerned with transnational rather than domestic terrorism. Oshita states that the concept of terrorism is used with reference to organizations such as Al Qaeda that are suspected to target Western interests which is by default considered to be international terrorism. ${ }^{23}$ Oshita goes further and notes that because the UN Security Council resolution 1373 of 2001 represents terrorism as essentially international in dimension, acts within the domestic space fall short of being terrorist for the purpose of the resolution. ${ }^{24}$

Ben Saul, on the other hand, argues that the UN Security Council's position has been changing from treating only international terrorism as a threat to international peace and security to embracing domestic terrorism as posing the

\footnotetext{
${ }^{18}$ The Security Council condemned the terrorist attack that took place on September the $9^{\text {th }}$ of 2001 in its resolution $1368(2001)$.

${ }^{19}$ Security Council verbatim debate, UN SCOR $57^{\text {th }}$ Sess., $4607^{\text {th }}$ Mtg, UN Doc S/PV.4607 (2002).

${ }^{20}$ The focus on international terrorism is explained in two ways. Some argue that attention is given to international terrorism for this but not domestic terrorism impact on Western interests. Jakkie Cilliers (2003), Terrorism and Africa, Essay. $<\mathrm{http} / / / \mathrm{www}$.issafrica.org/pubs/ASR/12No4/Cilliers.pdf $>$.Others attribute it to lack of information about domestic terrorism. Sanchez-Cuenca and de la Calle (2009), supra note 16.

${ }^{21}$ Cilliers (2003), supra note 20, p.101.

${ }^{22}$ Atta-Asamoah (2007), supra note 16, p. 20.

${ }^{23}$ Oshita O. Oshita, in Wafulu Okumu and Anneli Botha (eds.) (2007), "Domestic terrorism in Africa Ontology of an Old War in New Trenches", Domestic terrorism in Africa: Defining, addressing and understanding its impact on human security, p. 28.

${ }^{24}$ Ibid.
} 
same threat. ${ }^{25}$ Though a close reading of relevant Security Council resolutions, as argued below, does not seem to indisputably support Saul's position, his reference to "threat to international peace and security" as a criterion to identify which type of terrorism is/are within the mandate of the Security Council is helpful.

In his cogent examination of the Security Council's application of the 'threat to international peace and security' for about 60 years, Yamashita notes that the concept has been central in the Council's decision making. ${ }^{26}$ Davidsson emphasizes on the requirement of good faith on the part of the Security Council in characterizing threat ${ }^{27}$ which, as argued by O'Donnell, entails a focus on acting responsibly while deciding on the existence of threat on international peace and security. ${ }^{28}$ Many observe that it is the international nature of a threat that justifies the Security Council's action against it. ${ }^{29}$ As argued by Young, "[t]o engage the United Nations, as a political and legal matter, terrorism must have a significant international dimension." ${ }^{30}$ True, as provided under Article 24 of the UN Charter, the Security Council's mandate is closely intertwined with the maintenance of international peace and security.

It follows that whether resolution 1373 is applicable to both domestic and international terrorism or only to the latter depends on their impact on international peace and security. From his examination of the Security Council's resolutions passed to deal with threats on international peace and security for about 60 years, Yamashita concludes that the Council does not adopt a clear and universally applicable definition for a threat to international peace and security. ${ }^{31}$

${ }^{25}$ Ben Saul (2008), Reasons for Defining and Criminalizing 'Terrorism' in International Law, Legal Studies Research Paper No. 08/121, Sydney University Law School, p. 244. <http://ssrn.com/abstract=1291567>; Ben Saul, in Anamaria Salinas De Friasetal (2012), "Defining terrorism in International Law", Counterterrorism international law and practices, p. 71.

${ }^{26}$ Hikaru Yamashita (2007), Reading "Threats to International Peace and Security," 1946-2005, Diplomacy \& Statecraft, 18:3, p.551.

${ }^{27}$ Davidsson (2003), The U.N. Security Council's Obligations of Good Faith, 15 Florida J Int'l L, p. 541.

${ }^{28}$ Therese O'Donnell (2006), Naming and Shaming: The Sorry Tale of Security Council Resolution 1530 (2004), p. 951.

$<$ http://ejil.oxfordjournals.org/content/17/5/945.full\#xref-fn-13-1>

${ }^{29}$ Yamashita (2007), supra note 26, p.552; KarelWellens (2003), 'The UN Security Council and New Threats to the Peace: Back to the Future', $8 \mathrm{~J}$ Conflict \& Security L (2003) 15, p.42; N.D White (1997), Keeping the Peace, p.47.

${ }^{30}$ Reuven Young (2006), "Defining Terrorism: The Evolution of Terrorism as a Legal Concept in International Law and Its Influence on Definitions in Domestic Legislation", Boston College International and Comparative Law Review, Vol. 29, issue 1, p. 31.

${ }^{31}$ Yamashita (2007), supra note 26, pp. 551-572. 
The Council's understanding of the concept has been changing through time. During the cold war, invasion of a state and the resultant infringement of its sovereignty by another state and a civil war in which a foreign power is involved were considered as threats to international peace and security. ${ }^{32}$ After the cold war, the concept of threat to the peace was expanded to include three additional cases one of which being international terrorism. ${ }^{33}$ Rosand confirms that the Security Council, invoking Chapter VII of the Charter, declares international terrorism as a threat to "international peace and security". 34 O'Donnell, citing Hume, argues that it is terrorism's transnational threat that gives importance to counterterrorism. ${ }^{35}$ Relevant General Assembly resolutions for about thirty years and resolutions of the Commission on Human Rights since the 1990s confirm that international terrorism threatens international peace and security. ${ }^{36}$

Moreover, a survey of Security Council resolutions (passed before and after resolution 1373) and press releases ${ }^{37}$ relating to terrorism show that the Security Council has, in several occasions, linked international terrorism but not domestic terrorism with international peace and security. Resolution 1373 refers to two previous resolutions which declare international terrorism as a threat to international peace and security. ${ }^{38}$ The first resolution in which the Council explicitly associates threat to international peace and security with international terrorism is resolution 1269 (1999). In the first paragraph of its preamble, the Council expresses its deep concern with "the increase in acts of international

${ }^{32} I d$, p. 553

${ }^{33} I d$, pp. 561-62. The other two are systematic human rights violations or massive humanitarian crisis and development and possession of Weapons of Mass

Destruction. Id, pp. 555, 562.

34 Eric Rosand (2003), "Security Council Resolution 1373, The Counter-terrorism Committee, and the Fight against Terrorism", the American Journal of International Law, Vol. 97, No. 2, P. 333

${ }^{35}$ O'Donnell (2006), supra note 28, p. 953.

${ }^{36}$ Ben Saul, Three reasons for defining and criminalizing terrorism, p. 11. $<$ http://www.esil-sedi.eu/sites/default/files/Saul_0.PDF $>$

${ }^{37}$ In its several paragraphs Security Council Press release SC/7207 indicates that it is international terrorism which threatens international peace and security. It expressly indicates that the steps prescribed in Resolution 1373 are meant to combat international terrorism. Expert of Counter Terrorism Committee, in a briefing to Human Rights Committee, expressly indicates that states are required to take legislative and executive steps with a view to combat international terrorism. Press Release HR/CT/630 HUMAN RIGHTS COMMITTEE BRIEFED ON WORK OF COUNTERTERRORISM COMMITTEE

${ }^{38}$ Other resolutions passed before resolution 1373 suggesting a similar position of the Council include UNSC Resolutions 731 (1992); 748(1992); 1044(1996); 1189(1998); 1267 (1999); 1333(1999) and 1363 (2001). 
terrorism which endangers - the peace and security of all States." The eighth paragraph of the resolution's preamble reaffirms that it is the suppression of acts of international terrorism that it considers as an essential contribution to the maintenance of international peace and security. The other is resolution 1368 (2001) in which the Council affirms that 9/11 and other such terrorist acts, are acts of international terrorism, and that they constitute a threat to international peace and security.

Subsequent resolutions strengthen the position that the Security Council concerns itself with international terrorism. The preamble of resolution 1377 refers to Security Council resolutions 1269 (1999), 1368(2001) and 1373(2001), all of which, as argued above, deal with international terrorism, and it expressly indicates that "acts of international terrorism constitute one of the most serious threats to international peace and security in the twenty-first century." 39 Other paragraphs of the resolution identify acts of international terrorism that constitute a challenge to all States, as opposed to acts of domestic terrorism. Furthermore, the Council emphatically indicates that acts of international, not domestic, terrorism and involvement in their financing, planning and preparation as well as any other form of support are contrary to the purposes and principles of the Charter of the United Nations.

Security Council resolution 1566 (2004) imposes obligation on states to pass anti-terrorist laws, and it strengthens the argument that the Security Council requires States to deal with only international terrorism. The third paragraph of its operational part states that the Security Council:

Recalls that criminal acts, including against civilians, committed with the intent to cause death or serious bodily injury, or taking of hostages, with the purpose to provoke a state of terror in the general public or in a group of persons or particular persons, intimidate a population or compel a government or an international organization to do or to abstain from doing any act, which constitute offences within the scope of and as defined in the international conventions and protocols relating to terrorism, are under no circumstances justifiable by considerations of a political, philosophical, ideological, racial, ethnic, religious or other similar nature, and calls upon all States to prevent such acts and, if not prevented, to ensure that such acts are punished by penalties consistent with their grave nature. (Emphasis added)

The second limb of this paragraph in which the Security Council calls upon States to prevent or punish (as the case may be) the commission of terrorist acts envisaged in the first part of the paragraph indicates the scope of terrorist acts which the Security Council requires States to deal with. The first part of the

${ }^{39}$ Other resolutions passed after resolution 1373 suggesting a similar position of the Council include UNSC Resolutions 1390 (2002); 1455(2003); 1526(2004) and 1535(2004). 
paragraph in which the Security Council expresses its pre-existing position on terrorism, including its position under Resolution 1373, indicates that what are considered as unjustifiable terrorist acts under any circumstances are those acts which constitute offences within the scope of and as defined in the international conventions and protocols relating to terrorism. Thus, the counterterrorism obligation of states, as can be inferred from this paragraph, relates to terrorist acts which constitute the subject of international instruments relating to terrorism - i.e. international terrorism.

\section{Sporadic Use of the Word 'Terrorism' without Qualifiers and SC's Involvement in Domestic Terrorism Cases}

A close reading of the anti-terrorism resolutions shows that their reference to 'international' terrorism is not consistent. The resolutions which sporadically use the term 'terrorism' ${ }^{40}$ without the qualifying term 'international' evoke the question whether this warrants the inclusion of domestic terrorism within the ambit of the resolutions. In particular, resolution 1456 (2003) simply refers to 'terrorism' and 'terrorist acts'. Notably, in the first paragraph of its preamble, the Security Council reaffirms "terrorism in all its forms and manifestations constitutes one of the most serious threats to peace and security."

However, there are many reasons for this not to be construed as the Security Council treating domestic terrorism as a threat to international 'peace and security'. The Security Council, in this resolution, is reaffirming its position but not taking a new stance on the matter. The Council is expressing its emphasis on what it has already declared in previous resolutions. As discussed above that position is that it is international terrorism which is a threat to peace and security. In other resolutions, too, the context makes it clear that the sporadic reference to 'terrorism' without the adjective 'international' does not mean that the resolutions are intended to apply to domestic terrorism. ${ }^{41}$

${ }^{40}$ For example see: paragraphs 2,4 , and 7 of the preamble part and $1^{\text {st }}, 5$ th and $6^{\text {th }}$ paragraphs of the operational part of resolution 1269(1999); paragraphs 5-8 of preamble part and paragraphs $1(\mathrm{a}-\mathrm{d})$ and $2(\mathrm{a}-\mathrm{g})$ of operational part of resolution 1373.

${ }^{41}$ For example though under the $5^{\text {th }}$ paragraph of preamble part of resolution 1373 the Security Council reaffirms to combat 'terrorist' acts which threatens international peace and security, the term terrorist act should be read in light of the $3^{\text {rd }}$ paragraph of the resolution's preamble in which the Council expresses that it is international terrorism which impacts on international peace and security. Similarly, the reference to 'terrorism' or 'terrorist' acts having impact on international peace and security in the $1^{\text {st }}, 5^{\text {th }}$ and $6^{\text {th }}$ paragraphs of the operational part of resolution 1269 (1999), should be understood as referring to international terrorism as the link between this kind of terrorism and threat on international peace and security has already been established 
To support his argument that the Security Council treats domestic terrorism as a threat to international peace and security, Saul cites the Security Council's interest in what he considers domestic terrorist acts that took place in Russia and Spain. ${ }^{42}$ The Security Council expressed its concern in these acts in its two resolutions - resolution 1440(2002) relating to the 2002 Moscow hostage-taking and resolution 1530(2004) relating to the Madrid bombing in Spain.

Seemingly confirming Saul's position, both resolutions reaffirm resolution 1373 (2001), ${ }^{43}$ and they incorporate the following similarly phrased paragraphs. The Security Council, in the first paragraph of Resolution No. 1440 (2002),

Condemns in the strongest terms the heinous act of taking hostages in Moscow, the Russian Federation, on 23 October 2002, as well as other recent terrorist acts in various countries, and regards such acts, like any act of international terrorism, as a threat to international peace and security.

Similarly, the third paragraph of the Security Council resolution 1530,

Condemns in the strongest terms the bomb attacks in Madrid, Spain, perpetrated by the terrorist group ETA [Euskadi Ta Askatasuna] on 11 March 2004, in which many lives were claimed and people injured, and regards such act, like any act of terrorism, as a threat to peace and security;

It is noteworthy that in both cases the Security Council justifies its involvement in the matter indicating that peace and security is at stake. The Security Council regards the Moscow hostage taking as a threat to international peace and security like any act of international terrorism. This approach is similar to the one in resolution 1368 (2001) in which the Security Council regards the 9/11, like any act of international terrorism, as a threat to international peace and security. When it comes to the Madrid bombing, the Security Council has treated it as a threat to peace and security like any act of terrorism. In the resolution on the Madrid bombing, the term 'international' is not used to qualify the peace and security that is endangered and the terrorism that endangers it.

Both resolutions incorporate paragraphs which impart that both incidents trigger one of the obligations of states as provided under resolution 1373. In its $4^{\text {th }}$ paragraph, resolution 1440 :

Urges all States, in accordance with their obligations under resolution 1373 (2001), to cooperate with the Russian authorities in their efforts to find and bring to justice the perpetrators, organizers and sponsors of this terrorist attack.

in the preamble part which is to be assumed to have been in the mind of the security council while drafting the operational part of the resolution.

${ }^{42}$ Saul (2008), supra note 25, p. 244.

${ }^{43}$ First preambular paragraphs of both resolutions. 
In a similar fashion, resolution 1530 under its paragraph 3:

Urges all States, in accordance with their obligations under resolution 1373 (2001), to cooperate actively in efforts to find and bring to justice the Perpetrators, organizers and sponsors of this terrorist attack.

By stating that the Security Council urges all States, in accordance with their obligation under resolution 1373 (2001), to cooperate in efforts to bring to justice the perpetrators, organizers and sponsors of the attacks, both resolutions link the obligation of states under resolution 1373 to what Saul considers as domestic terrorist acts. ${ }^{44}$

Although some ${ }^{45}$ may characterize it as an international terrorist act owing to the resulting casualties which included foreigners (three Ukrainian, one American, and citizens of Armenia, Austria, Belarus, Kazakhstan and the Netherlands), ${ }^{46}$ conventionally, the Moscow hostage taking perpetrated by the Chechen radical militant group was a domestic terrorist act. ${ }^{47}$

The Security Council passed resolution 1530 on the assumption that ETA had committed the Madrid bombing. But there is consensus that the attribution to ETA was wrong. ${ }^{48}$ In view of the fact that the Security Council had never

${ }^{44}$ Two Presidential statements were also made, on behalf of the Security Council, relating to other terrorist acts that took place in Russia. One relates to the terrorist bomb attack that took place on 9 May 2004 in Grozny, the Russian Federation. SC Pres Stat (10 May 2004), S/PRST/2004/14. The other relates to the taking of hostages at a secondary school in the town of Beslan, the Russian Federation, on 1 September 2004. SC Pres Stat (1 September 2004), S/PRST/2004/31. Both statements, in their fifth paragraphs, remind states of their obligation under resolution 1373 to cooperate with authorities of the country where the crimes were committed as do resolutions 1440 and 1530. However, sources show that two Arabs were identified as being among the responsible for the September 2004 Beslal School hostage taking. McAllister, J.F.O and Paul Quinn-Judge. 2004. Defenseless Targets. Time Magazine, Sept 05.

$<\mathrm{http} / /$ content.time.com/time/magazine/article/0,9171,692846-1,00.html>

${ }^{45}$ For example, Sanchez-Cuenca and de la Calle (2009), supra note 16, p. 36; Reuven Young (2006), supra note 30, p.31.

${ }^{46}$ S.L. Myers (2002), HOSTAGE DRAMA IN MOSCOW: RUSSIA RESPONDS; PUTIN VOWS HUNT FOR TERROR CELLS AROUND THE WORLD, New York Time. October 29.

${ }^{47}$ O’Donnell (2006), supra note 28, p. 953.

${ }^{48}$ Ibid; Saul (2008), supra note 25, p. 244. Though direct link with Al-Qaeda could not be established during the investigation of the incident and trial of the suspects, the organization has declared as being responsible for the bombings in response to Spanish collaboration with the Bush administration in the global war against terrorism. BBC news (2004), Full text: 'Al-Qaeda' Madrid claim. 14 March.

$<$ http://news.bbc.co.uk/2/hi/europe/3509556.stm $\geq$ The Spanish judiciary initially stated its suspicion of involvement of "a loose group of Moroccan, Syrian, and Algerian Muslims." While several foreigners are reported to be suspected for 
reacted to domestic terrorist acts prior to the Madrid bombing, O'Donnell attributes the Security Council's involvement in the Madrid bombing more to illegitimate manoeuvring of the Spanish government and the Council's inherent European bias than to the Council's deliberate move to extend its mandate to domestic terrorism. ${ }^{49}$

On the other hand, O'Donnell ${ }^{50}$ notes that though the Council's involvement in a terrorist act committed by ETA appears to be questionable at first glimpse, ETA's connection to South America, Europe (in particular France from where it sometimes operates) and the Middle East, a fact acknowledged by Saul himself, ${ }^{51}$ would give the Madrid bombing a transnational character, thereby justifying the Security Council's resolution on the matter under its terms "threat on international peace and security".

\section{Plausible Interpretation of Resolution 1373}

From the preceding discussion the following alternative interpretations can be made on whether resolution 1373 is applicable to domestic terrorism.

a) In spite of numerous domestic terrorist acts, the Security Council has passed only two resolutions relating to two terrorist acts the domestic nature of which is questionable. These resolutions reminded states of their obligation, under resolution 1373, to cooperate with the authorities of states within the territories of which the acts were committed in bringing the perpetrators of the terrorist acts to justice. The two resolutions viewed in light of the enormous evidence that counter-terrorism resolutions in general and Resolution 1373 in particular are passed having international terrorism in mind ${ }^{52}$ are inadequate to show that resolution 1373 is applicable for domestic terrorism.

b) Even if the terrorist acts in Russia and Madrid are said to be purely domestic and Security Council's reference to states' obligation under resolution 1373 is considered to be indicative of the resolution's applicability to domestic terrorism, it would still be hasty to draw on this and conclude that resolution 1373 is meant to apply to all aspects of domestic terrorism for the following reasons.

involvement in the bombings one Moroccan was convicted for being among the persons who were involved in the Madrid bombings. BBC news (2005), Madrid bombing suspects, 10 March. $<$ http://news.bbc.co.uk/2/hi/europe/3560603.stm>

${ }^{49}$ O'Donnell (2006), supra note 28, pp. 948-53.

${ }^{50} \mathrm{Id}$, pp. $952-53$.

${ }^{51}$ Saul (2008), supra note 25, p. 244, note 208.

52 It is noteworthy that except in the above two concrete cases in none of the antiterrorism resolutions is express reference made to domestic terrorism in the abstract. 
i. It is only one of the obligations that resolution 1373 imposes on states--the duty of states to cooperate actively in efforts to find and bring to justice the perpetrators, organizers and sponsors of terrorist attack - which is invoked by both Security Council resolutions 1440 and 1530. Thus, the only plausible inference that can be made from the two resolutions is that regarding domestic terrorism, resolution 1373 requires states to cooperate, nothing more, with a state within the territory of which the domestic terrorist act is committed such as by supporting the state's authorities efforts to find and bring to justice the perpetrators, organizers and sponsors of the terrorist attack.

ii. Even the duty to cooperate is applicable to some but not all cases of domestic terrorism. Resolution 1440 suggests the test on whether a given domestic terrorism falls within Security Council Resolution 1373. As can be inferred from the resolution's $1^{\text {st }}$ paragraph, it is international terrorism that is normally considered as a threat to international peace and security and falls within the scope of resolution 1373. Exceptionally, some domestic terrorism cases might have the same effect on international peace and security as does international terrorism in which case it falls within resolution 1373. Saul, argues that acts of terrorism (both domestic and transnational) are threats to international peace and security, and acknowledges that not all domestic terrorist acts, but only serious acts of domestic terrorism that would have effect on international interests, can be considered as a threat to international peace ${ }^{53}$ without which a terrorist act cannot be within the reach of resolution 1373 .

Thus, the scant evidence on the applicability of resolution 1373 to domestic terrorism cases applies only to the obligation to cooperate in serious cases of domestic terrorism, and this has nothing to do with other obligations of states under resolution 1373 including the obligation to pass legislation that regulate domestic terrorism.

In light of the discussion above, the promulgation of Ethiopian antiterrorism law cannot be justified by resolution 1373. International counterterrorism instruments in general and resolution 1373 in particular do not seem to be applicable for cases of domestic terrorism. It is to be noted that many Ethiopians who are convicted under the anti-terrorism proclamation are living safely in various countries including the US, which leads global counterterrorism. ${ }^{54} \mathrm{Had}$

${ }^{53}$ Saul (2005), Definition of Terrorism in the UN Security Council, Chinese Journal of International Law, vol.4, no.1, p. 159-162.

$<\mathrm{http}$ //chinesejil.oxfordjournals.org/content/4/1/141.full.pdf $+\mathrm{html}>$

${ }^{54}$ In fact, the opposition, during the debate, points that it is because foreign states do not regard the Ethiopian terrorism prosecution and trial process as fair that in addition to providing safe heaven allow their institutions to grant awards to some of those who 
resolution 1373 been applicable to domestic terrorism, the Ethiopian government would have been able to invoke many of the provisions of the resolution to require foreign states, where its convicted citizens reside, to comply with their obligation under the resolution. For example, the government could have required concerned foreign states: to prohibit convicted Ethiopians from earning funds which are assumed to facilitate terrorist acts, and to freeze their funds and other financial assets or economic resources (Article 1(c \& d)); to deny safe heaven to those who are convicted for financing, planning and supporting terrorist acts (Article 2 (c )); to prevent those who are convicted for financing, planning, facilitating or committing terrorist acts from using their respective territories for those purposes against other States (Article 2(d)).

\section{Conclusion}

Two factors are said to constitute the raisons d'être for Ethiopia's anti-terrorism proclamation: threats of terrorist attacks and state's obligation to combat terrorism. As highlighted under Section 1, the terrorist attacks that occurred prior to 2002, which were not then considered 'serious enough' to call for special law have been used as evidence to justify the 2009 anti-terrorism proclamation. This ground can be valid only if the Ethiopian government concedes that it had unduly failed to appreciate the magnitude of the threat and that it overestimated the functional applicability of the criminal law and criminal procedure regimes prior to the enactment of the 2009 Anti-Terrorism Proclamation. However, a close reading of the 2002 report makes this possibility unlikely because the report indicates that the government has given the utmost consideration ${ }^{55}$ to the implementation of resolution 1373 from the beginning. It is with this level of attention that Ethiopia reiterates its position in its supplementary report of October 2002 by citing specific provisions of the law that the government believes to be relevant and adequate to fight terrorism and implement its Security Council Resolution1373 obligations.

True, the Criminal Code does not incorporate provisions that punish every act/intention that the anti-terrorism proclamation criminalizes and punishes. No doubt that as far as terrorism is concerned the proclamation has a broader scope,

are convicted for terrorism. For rewards for Reeyot Alemu, who is convicted for terrorism related crime and serving sentence see:

$<$ http://iwmf.org/honoring-courage/2012-courage-in-journalism-awards/awardees/reeyotalemu.aspx $>;<$ http://www.unesco.org/new/en/media-services/single-

view/news/ethiopian_journalist_reeyot_alemu_wins_2013_unesco_guillermo_cano_world_pr ess_freedom_prize/\#.UljEzqyVp8E $>$. For awards to Eskindir Nega, another convict, see: $\leq$ http://www.youtube.com/watch?v=QZB-cRycKdA $>$. For awards to both see: $<$ http://www.hrw.org/news/2012/12/20/ethiopia-4-journalists-win-free-speech-prize>

${ }^{55}$ The Report, supra note 7, p. 3 
a feature not liked by many, ${ }^{56}$ compared to the Criminal Code. This apparently gives much more power to the police and security officials compared to the 1961 Ethiopian Criminal Procedure Code. However, in view of the fact that the government's position was that the existing ordinary law is adequate to deal with the terrorist attacks that occurred prior to the report, to use the same terrorist attacks to show that the existing laws are inadequate and to justify the need for special law is at least unconvincing.

Drawing on the content of resolution 1373, other counterterrorism international legal instruments and related literature, it can be concluded that the Security Council Resolution 1373 does not require states to pass legislation on domestic terrorism. Ethiopia cannot thus invoke the resolution to justify its antiterrorism law which is being applied primarily on citizens.

However, this is far from concluding that the Ethiopian antiterrorism proclamation is not justified at all, nor does this article suggest that the opposition's claim is valid. The core argument of this article is that, the grounds mentioned during the debate as justifications for the promulgation of the law are not valid, subject to the caveat that this should not be misconstrued as an unqualified negation to the aptness of having an anti-terrorism law.

${ }^{56}$ See, for example, Amnesty International, supra note 1; Committee to Protect Journalists, supra note 1. 